\title{
External Debt and Financing of Economic Development: Evidence from North African Countries
}

\author{
Tarek Ben Ali and Tarek Sadraoui \\ Higher Institute of Business Administration, University of Gafsa, Tunisia
}

Correspondence should be addressed to: Tarek Ben Ali; tarek.benal@yahoo.fr

Received date: 26 April 2013; Accepted date: 4 August 2013; Published date: 30 September 2013

Copyright (C) 2013. Tarek Ben Ali and Tarek Sadraoui. Distributed under Creative Commons CC-BY 3.0

\begin{abstract}
Considering the economies of North Africa, the purpose of this research is to study the role of external debt in the financing of economic development. In particular, this paper examines the relationship between external debt and economic growth in North African economies. In fact, in recent years the south of the Mediterranean knows significant changes dictated mainly by the crisis of European sovereign debt and the large social manifestations in some Arabic countries. Foremost among these challenges is the issue of external debt and its role in financing economic development. The study was modelled on Patillo and al., (2002) and uses the technical panel. Combining the leading ratios of external debt and the main determinants of economic growth, we have verified the existence of an optimal threshold beyond which the external debt slows economic growth (there is a curve Laffer debt). For the North African countries, the empirical study shows that the external debt is not an obstacle to development when it contained within reasonable limits. Contrary, it can help these countries to strengthen their growth. However, an increase in debt service has a negative impact on economic growth and the transmission channel of this impact depends on the quality of the investment and the debt burden. Overall, the generated results suggest a nonlinear relationship between debt and growth: there is a critical threshold that would make a negative economic growth. This threshold, which corresponds to the marginal impact of debt on growth, reached $47 \%$ of GDP. The question remains whether public debt is indeed associated with higher growth below this turning point.
\end{abstract}

Keywords: financing of economic development, external debt, economic growth, North African economies, Panel data.

\section{Introduction}

The external debt was always considered as a natural consequence of economic activities. It comes from the fact that some countries or institutions have financial surpluses and other have financing needs.
The use of external debt allows a country to invest excess capital of its own financial resources by borrowing capital surpluses (Klein, 1994). Theoretically, debt created is supposed to generate growth and promote economic development. However, the debt crisis of the 1980's has challenged the 
assumption that the use of international borrowing allows to increase investment and promote development.

For developed countries, the current recession prevailing in these countries since the outbreak of the European debt crisis, let to believe that there is a negative relationship between the size of debt and economic growth. This correlation has been confirmed by several studies which were adequately described by Reinhart and Rogoff (2010). These authors have addressed this issue over long periods data concerning growth, inflation and debt of 20 industrialized countries and 24 developing countries. Both for developed countries and for emerging economies, they have shown that with a debt ratio above $90 \%$ of GDP, the relationship between public debt and economic growth is weak, but beyond this limits the growth is largely weakened. For developing countries, their study showed a fall of two points of the rate economic growth when the ratio of public debt exceeds $60 \%$ of GDP. However, economic growth becomes negative when this ratio exceeds $90 \%$ of GDP.

In this context, several theoretical arguments (Krugman 1988, Sachs 1989, Pattillo et al., 2002, Clements and al., 2003) showed that an increase in the ratio of public debt could lead to a reduction in growth due to crowding-out effect on private investment and the relative inefficiency of the state in the use of economic resources. Other arguments are often raised and especially foxed on the problem of fiscal sustainability caused by external debt which could lead the government to put in default or require a costly "inflation tax" leading to a slowdown in economic growth.

First this paper will be devoted to a review of the literature on the theoretical lessons on the relationship between external debt and economic growth, distinguishing the Keynesian approach and the neoclassical setting. The second section presents the model used and the results of various econometric tests. We will focus on the role of external debt in the financing of development. Especially it will be provided empirical evidence on the impact of high public debt on subsequent growth of real per capita GDP for a panel of developing market economies in the period 19902010. To do this, we will determine the impacts of foreign debt on development financing through the crowding-out effect of debt service and test the possible existence of a non-linear impact of debt on investment and growth (the relationship between the Laffer curve of debt and economic growth). Then we will look at how this effect debt manifests on the North African economies (transmission channels). The final section concludes the paper.

\section{External Debt and Economic Growth: Theoretical Lessons}

According to the theory of debt, public debt kept within reasonable limits can help countries to consolidate their growth. Indeed, when these countries use the borrowed funds to finance productive investment, growth is expected to accelerate and allow them to repay the debts at maturity.

However, when there is a likelihood that future external debt exceeds the repayment capacity of the country, the expected cost of debt service further discourage domestic and foreign investment and economic growth disadvantage (Corden (1988), Krugman (1988), Sachs (1989) and Pattillo al., (2002)). Thus, the high burden of servicing debt increases future taxes provided on the private sector, which consequently reduces private investment. Resources which are channeled for investment will be offset by the burden of debt service. Moreover, changing the quality of the investment, the debt can damage the economic performance and the uncertainty of repayment of debt service is a challenge to pursue economic reform (Clements et al., 2003). 
However, the relevance of the theory of indebtedness has been relativized by some authors who see the accumulation of debt is not the cause, but the consequence of low growth (Bulow and Rogoff (1990)) or the reduction debt would not be sufficient to restore investment and growth (Easterly (2002), Asiedu (2003)). In this context, other authors consider that rather the problems of developing countries in debt relating to liquidity (related to debt service) and not to incentives (related to the outstanding debt) (Cohen (1993), Claessens and Diwan (1989)).

So it seems that the impact of external debt on growth has not been a general consensus among economists. To identify further the nature of this impact, we will devote the next section to different theoretical interpretations of the impact of external debt on economic growth.

\section{Keynesian Conception of the Public Debt}

The Keynesian approach to the relationship between public debt and economic growth considers that the impact of government deficits on growth is considered positive. Indeed, in the case of a sub-activity, increased spending financed entirely by taxes, implicitly without impact on government debt, induces a corresponding increase in GDP ("Balanced Budget Multiplier"). According to the Keynesian approach, a reduction of taxation funded debt of the State consumption stimulates the short term. Indeed, a decrease in tax expense (not accompanied by a reduction in current or future public spending) increases the disposable income of households. Since consumption in the Keynesian perspective, is a proportional function of the income, then the effect of increasing the latter on consumption is positive. The increase in consumer spending will lead to an increase in aggregate demand, which will result in an equivalent increase in supply in the market balance of goods and services. Fine and all other things being equal, the funded public debt deficit implies an increase in production and income.
However, the Keynesian approach of the debt can not be valid in the medium and long term. Indeed, this approach characterized by the assumption of sticky prices and wages as well as the temporary myopia of economic agents can only work within a short period of reasoning. Longterm effects of a budget deficit threatening the sustainability of public finances are undeniably negative. These include an increase in long-term interest rates, due to an increase in the supply of government securities placed on the market and an increase in risk premiums. In addition, the increase in interest expense resulting from the worsening budget deficit reduces productive public spending and increasing taxation and social pressure. In other words, the public debt is reflected in the long term by reducing the savings which induces a contraction in investment. This in turn affects negatively the supply and consequently the production and income.

In an optical medium and long term, the transmission channel of debt on growth occurs primarily by a decrease in domestic investment and a contraction of the capital market. This reduces the production and income due to a scarcity of capital in the economy. As a result, the marginal productivity of capital is higher causing thus an increase in interest rates. With this increase in return on capital, labor productivity decreases, which consequently reduces the real wage rate in the economy and labor income. Moreover, the decrease in net foreign investment involves, firstly, the reduction of capital income residents invested abroad and, secondly, the decline in net exports and thus an increase in the current account deficit. This results in a current account deficit which induces an appreciation of the exchange rate and a deterioration of the competitiveness of the national economy.

\section{Neoclassical Setting of Public Debt}

In contrast to the Keynesian approach, Ricardian equivalence theory advanced by Robert Barro (1974) argues the thesis of a neutral public debt on economic growth. Under this approach, funding increased public spending deficit, we can expect that 
taxes are necessarily increased to serve or repay debt. As a result, consumers and businesses increase their savings rate in order to have sufficient funds to offset future tax liabilities. Moreover, rational consumers perceive any increase in the current fiscal deficit, due to a reduction in their tax burden financed by public debt, as an increase in their future tax burden, all other things being equal. Taking into account this additional tax burden future, households tend to maintain their consumption behavior unchanged and prefer to save all of their tax savings to cope with future tax deductions arising from the repayment of the debt. Therefore, though an increase in the public debt may lead to a higher private savings ratio, which will not be enough to compensate entirely for the decline in national net savings.

In dealing with the Ricardian equivalence theory, economists often refer to the fundamental ideas of the intertemporal budget constraint of the government and the permanent income hypothesis (Elmendorf and Mankiw (1998) and Ricciuti (2003)). For the intertemporal government budget constraint, we assume that government spending unchanged for a low level of current tax increase means higher future taxes. In other words, households perceive that any current reduction in their tax burden involves a partial transfer of this charge in the future. Concerning the permanent income hypothesis, it provides that households determine their consumption, not on the basis of their current income but rather from their permanent income. The latter is based on the present value of all net of tax current income. Since a tax cut that will be financed by debt does not affect the present value of the tax burden on households, it will not affect either their permanent income or their current consumption.

\section{Empirical Model, Data and Results}

The impact of external debt on economic growth has been the subject of several econometric researches and most of the results broadly confirm the theory of indebtedness, showing a negative impact of external debt on growth (Oks and Van Wijnbergen (1995), Agenor and Montiel (1999), Hansen (2001), Dijkstra and Hermes (2001), Clements et al., (2003), and Idlemouden Raffinot (2005), Swapan et al., (2007)). This negative effect often manifests itself through three main channels, namely the direct effect of high debt burden, crowding the debt service and the disincentive of the outstanding debt. From this point of view, it is necessary to reduce the external debt of developing countries (Deshpande (1997), Patillo et al., (2002), Clements et al., (2003), Cordella et al., (2005), Sen et al., (2007))). The effectiveness of the reduction was often reversed empirically, especially when it was measured by its direct effects on growth and the low-income countries (Arslanalp and Henry (2004, 2005, and 2006) Depetris and Kraay (2005), Presbitero (2009) and Johansson (2010)).

Other work (Pattillo et al., (2004) Maghyereh et al., (2002), Kumar and Woo (2010), Reinhart and Rogoff (2010a)) emphasize the positive impact of external debt on growth, showing this relationship as an inverted $U$ between the two variables. According to the curved shape, the debt has a positive impact on growth up to a certain level beyond that level or threshold, the effect of external debt on growth becomes negative.

\section{Specification of the Empirical Model}

For this study, the model used by Patillo et al., (2002) served as a frame of reference. By combining debt ratios and the main determinants of economic growth, these authors have produced satisfactory results. Our goal is, therefore, to study the impact of external debt on economic growth and to check if there is an optimal threshold beyond which the external debt slows economic growth (the existence of a potential curve Laffer debt). The equation of the growth model, taking 
into account the availability of data and North African region, is as follows: characteristics of the economies of the

$$
\begin{aligned}
& \text { TCPIBH }_{i, t}=\alpha_{i}+a_{1} \text { TCPIBHR }_{i, t-1}+a_{2} \text { TCD }_{i, t}+a_{3} \operatorname{TINV}_{i, t}+a_{4} \text { DCH }_{i, t}+a_{5} V T E_{i, t}+a_{5} \mathrm{OUV}_{i, t}+ \\
& a_{6} \operatorname{SDEXP}_{i, t}+a_{7} \text { DETPIB }_{i, t}+a_{8} \text { DETEXP }_{i, t}+a_{9} \operatorname{TINF}_{i, t}+\varepsilon_{i, t}
\end{aligned}
$$

Economic growth (endogenous variable) is approximated by the growth rate of real GDP per capita. As explanatory factors, we used the per capita income offset, the investment rate, secondary school enrollment, population growth (all in logarithm), the difference of policies (opening) and external shocks (terms of trade). To determine the effects of external debt, we added growth model commonly used standard three variables: the nominal value of outstanding external debt as a percentage of GDP and as a percentage of exports of goods and services, and debt service as a percentage of exports.

According to the previous specification, the variables of interest are the stock of debt and debt servicing. These variables allow us to test the two main assumptions of this study. The first assumption amounts to consider whether the payment of a very high debt service crowds out resources for investment, and therefore represents a barrier to economic growth. The second hypothesis focuses on the effect of future debt payments described by its assets. To check whether or not there is a nonlinear relationship between external debt and economic growth and consequently determine the optimal level of debt, we will follow two specifications: linear and quadratic. Regarding the first, it assumes a linear relationship, and each debt indicator is introduced in its normal form. In the second specification, we introduced the variable external debt as a percentage of GDP rose squared and the variable external debt as a percentage of exports of goods and services rose squared.

\section{Presentation of the Sample and Definition of Study Variables}

In this research, the sample consists of five countries of North Africa (Tunisia, Algeria,
Egypt, Morocco, and Mauritania). Considering this region, the choice of variables was made based on the availability of data and to obtain series which contain indebted countries, to determine the effect of the debt burden, and moderately indebted countries, which can show the effect of a moderate debt on economic growth. Using annual data, the study period covers 21 years and ranges from 1990 to 2010.

A set of explanatory variables that have been shown to be consistently associated with growth in the literature is fully taken into account:

- The growth rate of real GDP per capita lagged one period (TCPIBHR): this variable can have a great influence on the growth and allows us to test the hypothesis of unconditional convergence in a group of countries. The conditional convergence hypothesis implies that the coefficient on this variable is significantly negative. In this case, the control variables and individual specific effects capture the level of long-term income to which each country converges.

- The rate of population growth (TCD): an increase in the population could negatively influence the rate of economic growth. In other words, high population growth tends to impoverish a country because it is difficult to maintain a significant amount of capital per worker in the presence of a rapidly growing number of workers (Mankiw 2003).

- The investment rate (TINV): it indicates the share of total investment in GDP and reflects the impact of physical capital factor in the production process. Considered as a source of growth, this variable can increase physical capital, increase production, and therefore, increase the national income.

- As a proxy for human capital, we use
the log of average years of secondary
schooling in the population: it 
measures the development of human capital, which increases the productivity of workers, and thus their income, as well as that of the national economy.

- The openness degree of a country (OPEN): it is an indicator of trade openness. Most studies (theoretical and empirical) argue that when the country is sufficiently open to the outside, this allows it to boost its productivity and focus its scarce resources to more efficient sectors and thus improve its well-being.

- Debt ratios: with reference to previous studies, we used three indicators:

$>$ The servicing of external debt as a percentage of exports (SDEXP)

The nominal value of the outstanding external debt as a percentage of GDP (DEPIB)

And the nominal value of the outstanding external debt as a percentage of exports of goods and services (DETEXP).

External debt is intended to bridge the gap internal resources needed to finance growth. Indeed, the entry of foreign capital can strengthen the capacity of investment and thus cause an increase in national wealth. However, this increase means that the total debt is growing faster than the fundamental sources of income.

As previously stated, the introduction of these variables can test two hypotheses. The first is the existence of a nonlinear relationship between debt and growth, while the second is that the future payment of the outstanding indebtedness described by increasing the likelihood of an increase in the tax burden discourages domestic and foreign investments.

For debt service as a percentage of export earnings, it shows the vulnerability of commitments in which the payment of charges of debt service represents a risk of an unexpected drop in export earnings.
We note here that in order to distinguish between the crowding-out effect of debt and the theory of indebtedness (the existence of a relationship between the Laffer curve and growth), we used the service debt in relation to exports and debt indicators in the first and second degree. In theory, the service of the external debt (including interest and repayment of principal) can affect growth by crowding out private investment or changing the composition of public spending. The increase in interest expense may increase the fiscal deficit and thus reduce public savings, which result in an increase in interest rates or the crowding out of private investment, thereby slowing economic growth. Furthermore, the increased debt service may have a negative effect on growth by reducing the amount of public resources available for infrastructure and human capital formation.

In our estimates, the ratio of debt service to exports must have a negative sign to illustrate this crowding whereas the existence of the indebtedness theory, it is necessary that the sign of the coefficient of debt is positive and the sign of the coefficient of debt noted in square is negative. So, the peak of the quadratic equation will identify the level of debt stock where the marginal impact of debt on growth becomes negative.

- Change in the terms of trade (VTE): this variable captures the effects of external shocks in these economies especially since most of the countries considered are an exporter of raw materials. The expected sign is positive.

- Inflation Rate (TINF): according to most empirical work, this variable affects negatively real growth. Indeed, inflation increases the cost of capital, which reduces investment and hence economic growth. Moreover, the introduction of this variable in the growth equation can appear the "crowding out" effect of debt service payments (Agenor and Montiel, 1999). A high debt service can encourage governments to adopt inflationary 
policies which adversely affect investment and therefore economic growth.
The table below summarizes all the variables used and their data sources:

Table 1: list of study variables

\begin{tabular}{|c|c|c|c|}
\hline explanatory variables & Notation & $\begin{array}{l}\text { expected } \\
\text { sign }\end{array}$ & $\begin{array}{c}\text { statistical } \\
\text { Sources }\end{array}$ \\
\hline Growth rate of real GDP per capita lagged & TCPIBHR & negative & \multirow{10}{*}{$\begin{array}{l}\text { WDI, World } \\
\text { Bank, } 2012\end{array}$} \\
\hline Population Growth Rate & TCD & negative & \\
\hline $\begin{array}{l}\text { Rate of gross investment (public and private) as } \\
\text { a percentage of GDP }\end{array}$ & TINV & positive & \\
\hline secondary school enrolment rate & $\mathrm{DCH}$ & positive & \\
\hline Change in terms of trade & VTE & positive & \\
\hline trade openness & OUV & positive & \\
\hline $\begin{array}{l}\text { Total debt service (public and private) as a } \\
\text { percentage of export earnings }\end{array}$ & SDEXP & negative & \\
\hline External debt as a percentage of GDP & DETPIB & positive & \\
\hline $\begin{array}{l}\text { External debt as a percentage of exports of } \\
\text { goods and services }\end{array}$ & DETEXP & positive & \\
\hline Inflation Rate & TINF & negative & \\
\hline
\end{tabular}

\section{Interpretation of results}

\section{* Correlation Matrix}

The reading of the correlation matrix (Table 2) shows that the correlation coefficients are low for mostly used variables. The variables for which these coefficients are higher will not be considered jointly in the regressions.
We can conclude that there is no problem of multicollinearity since the correlation between variables is low (Levels of significance: $\quad * \quad 10$ percent) 
Table 2: Correlation Matrix

\begin{tabular}{|c|c|c|c|c|c|c|c|c|c|c|}
\hline Variables & TCPIBHR & LTCD & LDCH & OUV & LTINV & TINF & LSDEXP & LDETPIB & LDTEXP & VTE \\
\hline TCPIBHR & 1.000000 & & & & & & & & & \\
\hline LTCD & -0.191781 & 1.000000 & & & & & & & & \\
\hline LDCH & 0.220913* & $-0.871513^{*}$ & 1.000000 & & & & & & & \\
\hline OUV & $0.231900^{*}$ & $-0.953136^{*}$ & 0.834431 & 1.000000 & & & & & & \\
\hline LTINV & $0.144981^{*}$ & $-0.521524 *$ & 0.538383* & 0.655490 & 1.000000 & & & & & \\
\hline TINF & $-0.263613^{*}$ & $0.792112^{*}$ & -0.716167 & $-0.677050^{*}$ & -0.178242 & 1.000000 & & & & \\
\hline LSDEXP & $-0.153258^{*}$ & $0.833649^{*}$ & $-0.862357^{*}$ & $-0.869822^{*}$ & $-0.705951^{*}$ & $0.609145^{*}$ & 1.000000 & & & \\
\hline LDETPIB & $-0.174760^{*}$ & $0.843571^{*}$ & $-0.729227^{*}$ & $-0.911956^{*}$ & $-0.760110^{*}$ & $0.523367^{*}$ & $0.859255^{*}$ & 1.000000 & & \\
\hline LDTEXP & $-0.188232 *$ & $0.909892^{*}$ & $-0.821562^{*}$ & $-0.964163^{*}$ & $-0.740532 *$ & $0.597237^{*}$ & 0.900968* & $0.980570^{*}$ & 1.000000 & \\
\hline VTE & -0.046482 & 0.102807 & -0.230688 & $-0.016730^{*}$ & $0.331816^{*}$ & $0.274424^{*}$ & 0.043061 & $-0.218717 *$ & -0.117103 & 1.000000 \\
\hline
\end{tabular}

Tarek Ben Ali and Tarek Sadraoui(2013), Journal of North Africain Research in Business , DOI:10.5171/2013.335933. 
The descriptive statistics of the sample are shown in the table below.

Table 3: Descriptive Statistics

\begin{tabular}{|c|c|c|c|c|c|c|c|c|c|c|c|}
\hline & TCPIBH & TCPIBHR & $\overline{\text { VTE }}$ & $\overline{\text { OUV }}$ & SDEXP & $\overline{\text { TINF }}$ & $\overline{\mathrm{DCH}}$ & $\overline{T C D}$ & TINV & DTEXP & DETPIB \\
\hline Mean & 2.048282 & 1.996941 & 0.032165 & 0.520261 & 33.99914 & 4.642578 & 40.32430 & 1.634587 & 24.65497 & 271.6075 & 66.77635 \\
\hline Median & 2.074224 & 2.074224 & 0.040125 & 0.501008 & 33.43318 & 3.272366 & 38.00852 & 1.485912 & 24.21691 & 257.1808 & 69.77026 \\
\hline Maximum & 10.57687 & 10.57687 & 0.090604 & 0.777275 & 58.43904 & 12.49253 & 59.87814 & 2.675890 & 33.02131 & 510.5598 & 124.7602 \\
\hline Minimum & 998930 & -7.998930 & -0.047546 & 0.345708 & 12.07802 & 0.619802 & 25.69446 & 0.994579 & 19.39655 & 61.70953 & 23.42944 \\
\hline Std. Dev. & 4.609149 & 4.599138 & 0.034630 & 0.123504 & 13.28784 & 3.473016 & 8.765918 & 0.582928 & 3.504859 & 146.5158 & 29.57059 \\
\hline Sken & -0.359861 & -0.330129 & -0.493656 & 0.322760 & -0.073046 & 0.803219 & 0.786341 & 0.528282 & 0.681494 & 0.113372 & 0.054368 \\
\hline Kurtosis & 2.361173 & 2.365715 & 2.712843 & 1.981306 & 1.985563 & 2.603665 & 2.823548 & 1.877303 & 2.727378 & 1.703835 & 1.899092 \\
\hline Jarque-Bera & 5.788128 & 5.239114 & 6.607773 & 9.090207 & 6.565157 & 17.11078 & 15.65291 & 14.85484 & 12.07538 & 10.82161 & 7.648891 \\
\hline Probability & 0.055351 & 0.072835 & 0.036740 & 0.010619 & 0.037531 & 0.000193 & 0.000399 & 0.000595 & 0.002387 & 0.004468 & 0.021831 \\
\hline Sum & 307.2423 & 299.5412 & 4.824725 & 78.03915 & 5099.871 & 696.3867 & 6048.645 & 245.1880 & 3698.246 & 40741.13 & 10016.45 \\
\hline Sum Sq. Dev. & 3165.394 & 3151.658 & 0.178688 & 2.272717 & 26308.44 & 1797.214 & 11449.36 & 50.63092 & 1830.321 & 3198565 & 130288.6 \\
\hline Observations & 150 & 150 & 150 & 150 & 150 & 150 & 150 & 150 & 150 & 150 & 150 \\
\hline Cross sections & 5 & 5 & 5 & 5 & 5 & 5 & 5 & 5 & 5 & 5 & 5 \\
\hline
\end{tabular}

Tarek Ben Ali and Tarek Sadraoui(2013), Journal of North Africain Research in Business , DOI:10.5171/2013.335933. 


\section{* Stationary Series}

The unit root tests have become a common approach to the analysis of stationary time series. However, the implementation of these tests on panel data is recent. The most frequently used tests are those of Levin and Lin (1992) (LL) and Im, Pesaran and Shin (2003) (IPS).

Several procedures for the unit root tests and cointegration have been developed for models with panel data. The addition of the individual dimension to the temporal dimension has an advantage in terms of power in the implementation of the unit root tests and cointegration. In this section we applied different unit root tests of Levin and Lin (1992), ADF and the IPS test.

The application of unit root tests LL and IPS shows that all data series is assigned a unit root (Table 4). It should be noted that the maximum number of lags is set to 3 ; the selection of the number of lags for each individual is programmed by Pedroni for these two tests.

Table 4: Statistics Stationarity of LLC (2002)

\begin{tabular}{|c|c|c|}
\hline Variable & with constant & With constant and trend \\
\hline TCPIBH & -7.5862 & -7.5229 \\
& $0.0000)$ & $0.0000)$ \\
\hline TCPIBHR & -3.8307 & -2.6488 \\
& $(0.0001)$ & $-7.6040)$ \\
\hline LTCD & -5.1627 & $(0.0000)$ \\
\hline LTINV & $0.0000)$ & -4.2950 \\
& -2.1807 & $0.0000)$ \\
\hline LDCH & $0.0146)$ & -1.7168 \\
& -3.6981 & $0.0430)$ \\
\hline LVTE & $0.0001)$ & -4.9158 \\
& -6.1680 & $0.0000)$ \\
\hline OUV & $0.0000)$ & -1.8865 \\
& -2.8601 & $0.0303)$ \\
\hline LSDEXP & $0.0021)$ & -3.2135 \\
& -2.8515 & $0.0007)$ \\
\hline LDETEXP & $0.0234)$ & -6.8532 \\
& -9.5145 & $0.0000)$ \\
\hline LDETPIB & $0.0000)$ & -4.1411 \\
& -4.3463 & $0.0000)$ \\
\hline TINF & $(0.0000)$ & -5.1756 \\
& -3.9414 & $0.0000)$ \\
\hline
\end{tabular}

After checking properties nonstationarity for all variables of the panel considered, we conclude that the series in the panel are all integrated of order one (I (1)). As a result, we can now check the existence of a long-term relationship between the variables used, applying the cointegration tests of Pedroni (based on unit root tests on the estimated residuals).

\section{* Interpretation of Results}

The estimation results are presented in Tables 5, 6, 7 and 8. 
The tests were conducted by the Generalized Method of Moments (GMM) and fixed effects dynamic panel data. To ensure the robustness of the results in the estimation, we consider possible heteroscedasticity errors. In our study, the correction for heteroscedasticity was made by the method of White (Bourbonnais, 1998. In all regressions (GMM and fixed effects), the coefficient of lagged real barrier capita income is significantly negative at the $1 \%$, confirming the hypothesis of conditional convergence.

These results correspond to those found by Patillo et al., (2002), Clement et al., (2003),
Barro and Sala-i-Martin (1995) and Mankiw et al., (1992).

In accordance with the provisions of economic growth literature, the coefficient of the rate of population growth is significant and has the expected negative sign for most estimates in the linear and quadratic cases, reflecting a negative relationship between growth population and economic growth (Tables 4, 5, 6 and 7). This corroborates the results observed in several works such as Ojo and Oshikoya (1995).

Table 5: Estimation Results of the Growth Model

Debt Indicator, External Debt as a Percentage of Exports Dependent Variable: Growth Rate of Real GDP per Capita

\begin{tabular}{|c|c|c|c|c|c|c|}
\hline \multirow[b]{3}{*}{ Variables } & \multicolumn{2}{|c|}{ MCO } & \multicolumn{2}{|c|}{ Fixed effect } & \multicolumn{2}{|c|}{ GMM system } \\
\hline & (1) & (2) & (3) & (4) & (5) & (6) \\
\hline & $\begin{array}{c}\text { Linear } \\
\text { specificatio } \\
\mathbf{n}\end{array}$ & $\begin{array}{c}\text { Quadratic } \\
\text { specification }\end{array}$ & $\begin{array}{c}\text { Linear } \\
\text { specification }\end{array}$ & $\begin{array}{c}\text { Quadratic } \\
\text { specification }\end{array}$ & $\begin{array}{c}\text { Linear } \\
\text { specification }\end{array}$ & $\begin{array}{c}\text { Quadratic } \\
\text { specification }\end{array}$ \\
\hline TCPIBHR & $\begin{array}{c}-0.572976^{* * *} \\
(-10.0539) \\
\end{array}$ & $\begin{array}{c}-0.589976^{* * *} \\
(-10.0639)\end{array}$ & $\begin{array}{c}-1.572976^{* * *} \\
(-4.5431)\end{array}$ & $\begin{array}{c}-1.672976^{* * *} \\
(-4.0533) \\
\end{array}$ & $\begin{array}{c}-1.765729^{* * *} \\
(-2.1539) \\
\end{array}$ & $\begin{array}{c}-1.322976^{* * *} \\
(-2.0539)\end{array}$ \\
\hline LTCD & $\begin{array}{l}-1.686340 \\
(-2.81545)\end{array}$ & $\begin{array}{l}-1.978650 \\
(-2.53421)\end{array}$ & $\begin{array}{l}-1.879654 \\
(-2.97860)\end{array}$ & $\begin{array}{c}-1.765432 \\
(-3.123143)\end{array}$ & $\begin{array}{l}-1.987650 \\
(-1.98765)\end{array}$ & $\begin{array}{l}-1.897653 \\
(-2.05340)\end{array}$ \\
\hline LDCH & $\begin{array}{c}3.359952^{* * *} \\
(0.901178) \\
\end{array}$ & $\begin{array}{c}4.342349^{* * *} \\
(4.05390) \\
\end{array}$ & $\begin{array}{c}2.543640^{* *} \\
(3.25390) \\
\end{array}$ & $\begin{array}{c}3.503760^{* * *} \\
(2.06574) \\
\end{array}$ & $\begin{array}{l}2.324546 \\
(3.90765) \\
\end{array}$ & $\begin{array}{l}2.657432 \\
(2.53339) \\
\end{array}$ \\
\hline OUV & $\begin{array}{l}0.040000 \\
(0.81545) \\
\end{array}$ & $\begin{array}{r}0.040000 \\
(0.98345) \\
\end{array}$ & $\begin{array}{l}0.060000 \\
(1.81587) \\
\end{array}$ & $\begin{array}{l}0.060000 \\
(1.75643) \\
\end{array}$ & $\begin{array}{c}0.020000 \\
(0.888453)\end{array}$ & $\begin{array}{c}0.020000 \\
(0.887565)\end{array}$ \\
\hline LTINV & $\begin{array}{c}4.414910^{* * *} \\
(3.213456)\end{array}$ & $\begin{array}{c}4.634242^{* * *} \\
(1.98539)\end{array}$ & $\begin{array}{c}3.231429^{* * *} \\
(2.52379)\end{array}$ & $\begin{array}{c}3.729760^{* * *} \\
(2.43539)\end{array}$ & $\begin{array}{l}1.672963^{*} \\
(1.52239)\end{array}$ & $\begin{array}{l}1.532427^{*} \\
(1.43536)\end{array}$ \\
\hline TINF & $\begin{array}{c}-0.058400 \\
(-0.412683) \\
\end{array}$ & $\begin{array}{c}-0.005147 \\
(-0.038264) \\
\end{array}$ & $\begin{array}{l}-9.686340 \\
(-2.81545)\end{array}$ & $\begin{array}{l}-9.686340 \\
(-2.81545)\end{array}$ & $\begin{array}{c}-0.124935 \\
(-0.474674) \\
\end{array}$ & $\begin{array}{c}-0.048776 \\
(-0.169067) \\
\end{array}$ \\
\hline LSDEXP & \begin{tabular}{|c|}
-3.019160 \\
$(-2.019633)$
\end{tabular} & $\begin{array}{c}-1.875871 \\
(-1.304871) \\
\end{array}$ & $\begin{array}{c}-3.01916^{* * *} \\
(-1.990361) \\
\end{array}$ & $\begin{array}{l}-2.573576 \\
(-1.45649)\end{array}$ & $\begin{array}{l}-2.781594^{*} \\
(-2.221182) \\
\end{array}$ & $\begin{array}{l}-2.148397 \\
-2.363554) \\
\end{array}$ \\
\hline LDETEXP & $\begin{array}{l}9.686340 \\
(2.81545) \\
\end{array}$ & $\begin{array}{c}8.911811 \\
(4.791218)\end{array}$ & $\begin{array}{r}7.827544 \\
(2.318679)\end{array}$ & $\begin{array}{l}9.686340 \\
(2.81545) \\
\end{array}$ & $\begin{array}{c}6.212222 \\
(2.019718)\end{array}$ & $\begin{array}{c}6.634257 \\
(1.839013)\end{array}$ \\
\hline LDTEXP $^{2}$ & & $\begin{array}{c}-9.087506 \\
(-4.580059)\end{array}$ & & $\begin{array}{c}-5.875640 \\
(-2.0539) \\
\end{array}$ & & $\begin{array}{c}-5.981810 \\
(-2.689588) \\
\end{array}$ \\
\hline VTE & $\begin{array}{c}3.520174 \\
(0.359416) \\
\end{array}$ & $\begin{array}{r}9.686340 \\
(2.81545) \\
\end{array}$ & $\begin{array}{r}3.520174 \\
(0.354206)\end{array}$ & $\begin{array}{l}3.342507 \\
(2.81545) \\
\end{array}$ & $\begin{array}{c}4.791071 \\
(0.278561)\end{array}$ & $\begin{array}{c}10.96090 \\
(0.554440)\end{array}$ \\
\hline Constante & $\begin{array}{c}104.7890^{* * *} \\
(5.601)\end{array}$ & $\begin{array}{c}147.0126^{* * *} \\
(5.519636) \\
\end{array}$ & $\begin{array}{c}104.7890^{* * *} \\
(5.601)\end{array}$ & $\begin{array}{r}69.7989 * * * \\
(3.40104) \\
\end{array}$ & $\begin{array}{c}124.6331^{* * *} \\
(1.956931) \\
\end{array}$ & $\begin{array}{c}118.7579 * * * \\
(1.781364) \\
\end{array}$ \\
\hline $\mathbf{R}^{2}$ & 0.642842 & 0.691185 & 0.642842 & 0.638281 & 0.582632 & 0.677196 \\
\hline
\end{tabular}


Table 6: Estimation Results of the Growth Model

Debt Indicator, External Debt as a Percentage of GDP

Dependent Variable: Growth Rate of Real GDP per Capita

\begin{tabular}{|c|c|c|c|c|c|c|}
\hline \multirow{3}{*}{ Variables } & \multicolumn{2}{|c|}{ MCO } & \multicolumn{2}{|c|}{ Fixed effect } & \multicolumn{2}{|c|}{ GMM system } \\
\hline & (1) & (2) & (3) & (4) & (5) & (6) \\
\hline & $\begin{array}{c}\text { Linear } \\
\text { specification }\end{array}$ & $\begin{array}{c}\text { Quadratic } \\
\text { specification }\end{array}$ & $\begin{array}{c}\text { Linear } \\
\text { specification }\end{array}$ & $\begin{array}{c}\text { Quadratic } \\
\text { specification }\end{array}$ & $\begin{array}{c}\text { Linear } \\
\text { specification }\end{array}$ & $\begin{array}{c}\text { Quadratic } \\
\text { specification }\end{array}$ \\
\hline TCPIBHR & $\begin{array}{c}-0.572976^{* * *} \\
(-10.0539)\end{array}$ & $\begin{array}{c}-1.213459^{* * *} \\
(-6.75432) \\
\end{array}$ & $\begin{array}{c}-1.572976^{* * *} \\
(-4.54325)\end{array}$ & $\begin{array}{c}-1.672976^{* * *} \\
(-4.0533)\end{array}$ & $\begin{array}{c}-1.765729 * * * \\
(-2.1539) \\
\end{array}$ & $\begin{array}{c}-0.322976^{* * *} \\
(-6.0529)\end{array}$ \\
\hline LTCD & $\begin{array}{l}-1.686340 \\
(-2.81545)\end{array}$ & $\begin{array}{l}-1.967650 \\
(-2.53421)\end{array}$ & $\begin{array}{l}-1.879654 \\
(-2.97860)\end{array}$ & $\begin{array}{c}-1.765432 \\
(-3.123143)\end{array}$ & $\begin{array}{l}-1.987650 \\
(-1.98765)\end{array}$ & $\begin{array}{l}-1.897653 \\
(-2.05340)\end{array}$ \\
\hline LDCH & $\begin{array}{c}3.359952^{* * *} \\
(0.901178)\end{array}$ & $\begin{array}{c}3.342876^{* * *} \\
(2.05390)\end{array}$ & $\begin{array}{c}2.543640^{* *} \\
(3.25390)\end{array}$ & $\begin{array}{c}3.503760^{* * *} \\
(2.06574)\end{array}$ & $\begin{array}{l}2.324546 \\
(3.90765)\end{array}$ & $\begin{array}{l}2.657432 \\
(2.53339)\end{array}$ \\
\hline OUV & $\begin{array}{c}0.040000 \\
(0.81545) \\
\end{array}$ & $\begin{array}{r}0.060000 \\
(0.97345) \\
\end{array}$ & $\begin{array}{l}0.070000 \\
(1.81587) \\
\end{array}$ & $\begin{array}{c}0.050000 \\
(1.795643)\end{array}$ & $\begin{array}{c}0.030000 \\
(0.872313)\end{array}$ & $\begin{array}{c}0.020000 \\
(0.896765)\end{array}$ \\
\hline LTINV & $\begin{array}{c}4.414910^{* * *} \\
(3.213456)\end{array}$ & $\begin{array}{c}3.635442^{* * *} \\
(2.039039)\end{array}$ & $\begin{array}{c}3.231429^{* * *} \\
(2.52379)\end{array}$ & $\begin{array}{c}3.729760^{* * *} \\
(2.43539)\end{array}$ & $\begin{array}{l}1.672963^{*} \\
(1.52239)\end{array}$ & $\begin{array}{l}1.532427^{*} \\
(1.43536)\end{array}$ \\
\hline TINF & $\begin{array}{c}-0.058400 \\
(-0.412683)\end{array}$ & $\begin{array}{c}-0.004256 \\
(-0.044320)\end{array}$ & $\begin{array}{l}-9.686340 \\
(-2.81545)\end{array}$ & $\begin{array}{l}-9.686340 \\
(-2.81545)\end{array}$ & $\begin{array}{c}-0.124935 \\
(-0.474674)\end{array}$ & $\begin{array}{c}-0.048776 \\
(-0.169067)\end{array}$ \\
\hline LSDEXP & $\begin{array}{c}-3.019160 \\
(-2.019633) \\
\end{array}$ & $\begin{array}{l}-1.903450 \\
(-1.60461) \\
\end{array}$ & $\begin{array}{c}-3.019160 \\
(-1.990361) \\
\end{array}$ & $\begin{array}{l}-2.573576 \\
(-1.45649) \\
\end{array}$ & $\begin{array}{c}-2.619470 * \\
(-2.04182) \\
\end{array}$ & $\begin{array}{c}-2.148397 \\
-2.363554) \\
\end{array}$ \\
\hline LDETPIB & $\begin{array}{l}9.686340 \\
(2.81545) \\
\end{array}$ & $\begin{array}{l}8.786541 \\
(3.93218) \\
\end{array}$ & $\begin{array}{r}7.827544 \\
(2.318679) \\
\end{array}$ & $\begin{array}{c}7.43532 \\
(3.70435) \\
\end{array}$ & $\begin{array}{l}4.564320^{* *} \\
(2.019718)\end{array}$ & $\begin{array}{c}6.634257 \\
(1.839013)\end{array}$ \\
\hline LDETPIB $^{2}$ & & $\begin{array}{l}-3.087306^{* *} \\
(-2.580059) \\
\end{array}$ & & $\begin{array}{c}-3.861240^{* * *} \\
(-2.0539)\end{array}$ & & $\begin{array}{l}-2.1843530 \\
(-1.969558)\end{array}$ \\
\hline VTE & $\begin{array}{c}3.520174 \\
(0.359416) \\
\end{array}$ & $\begin{array}{l}5.632552 \\
(1.91535) \\
\end{array}$ & $\begin{array}{r}3.532410 \\
(0.354206) \\
\end{array}$ & $\begin{array}{l}2.342546 \\
(2.01545) \\
\end{array}$ & $\begin{array}{c}3.734371 \\
(0.178561) \\
\end{array}$ & $\begin{array}{c}8.954690 \\
(0.554440) \\
\end{array}$ \\
\hline Constante & $\begin{array}{c}44.74390^{* * *} \\
(2.63401) \\
\end{array}$ & $\begin{array}{l}47.4353^{* * *} \\
(3.654642)\end{array}$ & $\begin{array}{c}104.7890^{* * *} \\
(3.65460) \\
\end{array}$ & $\begin{array}{r}59.6799 * * * \\
(3.40104) \\
\end{array}$ & $\begin{array}{c}24.66782^{* * *} \\
(1.956931) \\
\end{array}$ & $\begin{array}{c}38.7079 * * * \\
(2.68164) \\
\end{array}$ \\
\hline $\mathbf{R}^{2}$ & 0.542842 & 0.591185 & 0.648842 & 0.638281 & 0.582632 & 0.677196 \\
\hline
\end{tabular}

For all estimations, the coefficients for the variable "investment rate" have the expected signs. However, their statistical significance is verified only in the case of OLS and fixed effects (specification 1, 2, 3 and 4 of Tables 5 and 6). This confirms the theory that considers the development of a country going mostly by the effort in terms of productive investment. Beyond the short-term effects of investment in the economy, it has a decisive influence on the level of a country's sustainable growth.

For the development of human capital, it has a positive and significant impact on economic growth in the majority of linear and quadratic estimates, which justifies the fact that education is often seen as the cornerstone of economic development. However, we must be careful with this indicator because it does not take into account the qualifications and thus the effectiveness.

The results indicate that changes in the terms of trade have a positive and significant impact on growth in most estimates. 
The coefficient of trade openness rate, with low significance, contributes positively to economic growth. Indeed, economic openness allows the economy to benefit from technology transfer and various forms of positive externalities and drives external demand effects. Also, the opening on the outside allows countries to obtain, where necessary, improved borrowing conditions in the international market. On the other hand, the international competitiveness of a country depends to a more open trade, demanding an increase in factor productivity, promotion of activities with high added value and export-oriented and a relaxation of functioning of the labor market. Diversification and the best compensation exports are a key for competitiveness.

Considered as a key indicator of the quality of the economic environment, inflation was introduced in the growth equation to show the Crowding out of private investment by debt service. A high debt service often leads governments to adopt inflationary policies that may adversely affect investment and therefore economic growth (Agenor and Montiel (1999)). The estimates highlight negative coefficients of inflation rates which are statistically significant. This is consistent with the results expected by the economic theory.

An increase in the debt service has a negative and significant impact on economic growth for all estimations. Thus, and as we have already mentioned, the debt ratio measures the proportion of external debt service covered by the gross domestic product. This variable is a highly useful indicator because it monitors the country's debt level. When it is high, it could prevent countries to devote sufficient resources to productive activities. These results corroborate the work of Pattillo et al., (2002) which showed that the impact of this variable on economic growth is either insignificant or negative and significant. So, the debt service affects growth through its impact on the quality of investment or through the high volume of debt.
By applying the linear model, the results observed indicate that external debt reported successively to GDP and exports of goods and services has a positive and significant growth in line with those predicted by economic theory. Thus, viewed as a tool of external financing for investment, external debt in itself is not an obstacle to development in these countries, which often suffer from a lack of internal resources. As more empirical work emphasizes, this is when the external debt reaches a certain level it becomes a handicap to growth (Patillo et al., (2002), Reinhart and Rogoff (2010), Cecchetti, Mohanty and Zampolli (2011), Checherita and Rother (2010)). From such a level of debt, the marginal efficiency of borrowed currency falls below the interest rate applied to the repayment of external debt.

The estimation of the quadratic model was performed to test the hypothesis of diminishing marginal returns of foreign debt, otherwise to check the non-linear effect of external debt on economic growth. In line with the work of Lensink and White (1999), Hansen and Tarp $(2000,2001)$, Dalgaard and Hansen (2001), Collier and Dollar (2002) and Patillo et al., (2002), we estimated the growth model by taking the square of the debt indicator (specifications $3,4,7$ and 8 of Tables 5 to 10 ).

Thus, the coefficients of the two variables taken in square (external debt as a percentage of GDP and external debt as a percentage of exports) are negative and statistically significant, according to the results of Clement et al., (2003). In other words, the external debt affects positively economic growth if it does not exceed a certain threshold. Beyond this threshold, the effect becomes negative. This allows us to opt for the existence of a nonlinear relationship between debt and growth, and therefore there is a critical threshold that would make a negative growth.

To illustrate the link between investment and debt service (through the crowding out effect), we estimated the growth model without investment (specifications 7, 8, 9 and 10 in Tables 5 and 6). This allows us to test the hypothesis that part of the debt 
effect is embedded in a lower investment ratio, which may bias the estimation results. Thus, when the effect of debt is much more important, if the investment is excluded from the estimate, we can conclude that a high debt reduces the investment rate. However, when this difference is negligible it can be inferred that the main channel through which debt affects economic growth is rather the quality and efficiency of investment (Pattillo et al., 2002).

In light of this explanation, the estimations show that the coefficients related to the variables of debt (DETPIB, DETEXP) are significant and at the same time different from those obtained in the presence of investment. In other words, the ratio of debt service remains significant indicating that the adverse effect through crowding, but also directly affects the rate of economic growth. In other words, the ratio of debt service remains significant indicating that its negative impact is done through crowding out effect, and directly affects the rate of economic growth.

The generated results allow us to conclude that the theory of indebtedness is checked. Therefore, there is according to the results of Clement et al (2003) a relationship between debt and growth taking the form of an inverted $U$ and indicating the existence of a Laffer curve of debt.

Table 7: Results of the Growth Model: Nonlinear Effect of External Debt.

Debt Indicator, External Debt as a Percentage of Exports Dependent Variable: Growth rate of Real GDP per Capita

\begin{tabular}{|c|c|c|c|c|}
\hline \multirow{3}{*}{ Variables } & \multicolumn{2}{|c|}{ MCO } & \multicolumn{2}{|c|}{ fixed effect } \\
\hline & (A) & (B) & (C) & (D) \\
\hline & $\begin{array}{c}\text { Linear } \\
\text { specification }\end{array}$ & $\begin{array}{c}\text { Quadratic } \\
\text { specification }\end{array}$ & $\begin{array}{c}\text { Linear } \\
\text { specification }\end{array}$ & $\begin{array}{c}\text { Quadratic } \\
\text { specification }\end{array}$ \\
\hline TCPIBHR & $\begin{array}{c}-0.172451^{* * *} \\
(-2.117885)\end{array}$ & $\begin{array}{c}-0.199114^{* * *} \\
(-2.472312)\end{array}$ & $\begin{array}{c}-0.163312^{* * *} \\
(-2.016822)\end{array}$ & $\begin{array}{l}-0.18849 * * * \\
(-2.351335)\end{array}$ \\
\hline LTCD & $\begin{array}{c}-2.669322^{* * *} \\
(-2.199132) \\
\end{array}$ & $\begin{array}{c}-2.426079^{* * *} \\
(-2.031272) \\
\end{array}$ & $\begin{array}{c}-0.2065339 * * * \\
(-2.156006)\end{array}$ & $\begin{array}{r}-0.237129 \\
(-1.9842) \\
\end{array}$ \\
\hline LDCH & $\begin{array}{c}0.572170 \\
(0.610503) \\
\end{array}$ & $\begin{array}{c}0.013212 \\
(0.013953) \\
\end{array}$ & $\begin{array}{l}0.0554760 \\
(2.591851) \\
\end{array}$ & $\begin{array}{c}0.020281 \\
(2.021390) \\
\end{array}$ \\
\hline OUV & $\begin{array}{c}1.366840 \\
(1.096535) \\
\end{array}$ & $\begin{array}{l}1.121103 \\
(2.57788) \\
\end{array}$ & $\begin{array}{c}0.215197 \\
(1.960018) \\
\end{array}$ & $\begin{array}{r}0.10059 \\
(2.78007) \\
\end{array}$ \\
\hline LTINV & $\begin{array}{c}0.378027^{* * *} \\
(2.040962) \\
\end{array}$ & $\begin{array}{c}0.153643^{* * *} \\
(2.172870) \\
\end{array}$ & & \\
\hline TINF & $\begin{array}{c}-0.006593^{* * *} \\
(-2.134687) \\
\end{array}$ & $\begin{array}{c}-0.007519^{* * *} \\
(-2.132727) \\
\end{array}$ & $\begin{array}{c}-0.022471^{* * *} \\
(-2.406450) \\
\end{array}$ & $\begin{array}{c}-0.0017154^{* * *} \\
(-2.127835) \\
\end{array}$ \\
\hline LSDEXP & $\begin{array}{c}-0.170437 \\
(-3.135358) \\
\end{array}$ & $\begin{array}{l}-0.2116742 \\
(-3.802624) \\
\end{array}$ & $\begin{array}{l}-0.1971298 \\
(-3.626871) \\
\end{array}$ & $\begin{array}{l}-0.1581003 \\
(-2.979924) \\
\end{array}$ \\
\hline LDTEXP & $\begin{array}{c}1.100839 \\
(1.742395) \\
\end{array}$ & $\begin{array}{c}0.603823^{* * *} \\
(2.973626) \\
\end{array}$ & $\begin{array}{c}0.927179 \\
(1.521091) \\
\end{array}$ & $\begin{array}{c}0.6296134^{* * *} \\
(2.851040) \\
\end{array}$ \\
\hline LDTEXPC $^{2}$ & & $\begin{array}{c}-0.589908 \\
(-2.580443) \\
\end{array}$ & 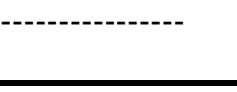 & $\begin{array}{c}-0.577572 \\
(-2.525732) \\
\end{array}$ \\
\hline VTE & $\begin{array}{l}0.831602 \\
(1.79194) \\
\end{array}$ & $\begin{array}{c}1.121103 \\
(1.091803) \\
\end{array}$ & $\begin{array}{c}0.858525 \\
(0.825085) \\
\end{array}$ & $\begin{array}{c}1.14991 \\
(1.113704) \\
\end{array}$ \\
\hline LDETPIB & $\begin{array}{c}0.783251^{* * *} \\
(2.88753) \\
\end{array}$ & $\begin{array}{c}0.568932^{* * *} \\
(2.56352) \\
\end{array}$ & $\begin{array}{c}1.950902^{* * *} \\
(2.596851) \\
\end{array}$ & \\
\hline
\end{tabular}




\begin{tabular}{|c|c|c|c|c|}
\hline \multirow{2}{*}{ Variables } & \multicolumn{2}{|c|}{ MCO } & \multicolumn{2}{c|}{ fixed effect } \\
\cline { 2 - 5 } & $(\mathbf{A})$ & $(\mathbf{B})$ & $(\mathbf{C})$ & $(\mathbf{D})$ \\
\cline { 2 - 5 } & $\begin{array}{c}\text { Linear } \\
\text { specification }\end{array}$ & $\begin{array}{c}\text { Quadratic } \\
\text { specification }\end{array}$ & $\begin{array}{c}\text { Linear } \\
\text { specification }\end{array}$ & $\begin{array}{c}\text { Quadratic } \\
\text { specification }\end{array}$ \\
\hline Constante & 2.4077623 & 11.09402 & 2.100002 & 5.83697 \\
\hline $\mathbf{R}^{\mathbf{2}}$ & 0.271841 & 0.208687 & 0.165609 & 0.201005 \\
\hline Note: The Student statistic (t) in brackets, * Significant at 10\% ** Significant at 5\% *** \\
Significant at 1\% \\
\hline
\end{tabular}

Table 8: Results of the Growth Model: Nonlinear Effect of External Debt Debt Indicator, External Debt as a Percentage of GDP Dependent Variable: Growth Rate of Real GDP per Capita

\begin{tabular}{|c|c|c|c|c|}
\hline \multirow{3}{*}{ Variables } & \multicolumn{2}{|c|}{ MCO } & \multicolumn{2}{|c|}{ fixed effect } \\
\hline & (A) & (B) & (C) & (D) \\
\hline & $\begin{array}{c}\text { Linear } \\
\text { specification }\end{array}$ & $\begin{array}{c}\text { Quadratic } \\
\text { specification }\end{array}$ & $\begin{array}{c}\text { Linear } \\
\text { specification } \\
\end{array}$ & $\begin{array}{c}\text { Quadratic } \\
\text { specification }\end{array}$ \\
\hline TCPIBHR & $\begin{array}{c}-0.1187091^{* * *} \\
(-3.712885)\end{array}$ & $\begin{array}{l}-0.21805^{* * *} \\
(-1.985412)\end{array}$ & $\begin{array}{c}-0.170599^{* * *} \\
(-2.022768)\end{array}$ & $\begin{array}{c}-0.204341^{* * *} \\
(-2.54353)\end{array}$ \\
\hline LTCD & $\begin{array}{c}-1.96244 \\
(-2.91222) \\
\end{array}$ & $\begin{array}{l}-1.822110 \\
(-2.37245) \\
\end{array}$ & $\begin{array}{l}-2.093860 \\
(-2.64596) \\
\end{array}$ & $\begin{array}{l}-1.934385 \\
(-1.98762) \\
\end{array}$ \\
\hline LDCH & $\begin{array}{c}1.056019 \\
(0.919873) \\
\end{array}$ & $\begin{array}{c}0.234343 \\
(0.786540) \\
\end{array}$ & $\begin{array}{r}0.893090 \\
(1.98765) \\
\end{array}$ & $\begin{array}{c}0.066952 \\
(1.967540) \\
\end{array}$ \\
\hline OUV & $\begin{array}{c}0.03175 \\
(1.90535) \\
\end{array}$ & $\begin{array}{c}0.03515 \\
(1.97388) \\
\end{array}$ & $\begin{array}{c}0.216867 \\
(1.964590)\end{array}$ & $\begin{array}{c}0.2635007 \\
(1.897992)\end{array}$ \\
\hline LTINV & $\begin{array}{c}2.041398 \\
(2.624353) \\
\end{array}$ & $\begin{array}{r}1.812265 \\
(2.72876) \\
\end{array}$ & ---- & \\
\hline TINF & $\begin{array}{c}-0.00199 \\
(-2.334755) \\
\end{array}$ & $\begin{array}{c}-0.004964 \\
(-2.033427) \\
\end{array}$ & $\begin{array}{c}-0.002377 \\
(-2.356750) \\
\end{array}$ & $\begin{array}{l}-0.015186 \\
(-2.15635) \\
\end{array}$ \\
\hline LSDEXP & $\begin{array}{l}-1.664237 \\
(-2.35878)\end{array}$ & $\begin{array}{l}-2.137958 \\
(-2.02614)\end{array}$ & $\begin{array}{c}-1.510207 \\
(-3.101210)\end{array}$ & $\begin{array}{l}-2.015112 \\
(-2.09024)\end{array}$ \\
\hline LDTEXP & $\begin{array}{c}0.664230 \\
(2.757865) \\
\end{array}$ & $\begin{array}{c}0.851270 \\
(2.726043) \\
\end{array}$ & $\begin{array}{c}0.52136 \\
(1.921071) \\
\end{array}$ & $\begin{array}{c}0.800229 \\
(2.108740) \\
\end{array}$ \\
\hline LDETPIBC 2 & --- & $\begin{array}{l}-0.783339 \\
(-3.84043)\end{array}$ & 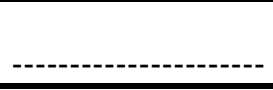 & $\begin{array}{l}-0.805516 \\
(-3.22876) \\
\end{array}$ \\
\hline VTE & $\begin{array}{r}0.681598 \\
(1.99194) \\
\end{array}$ & $\begin{array}{l}1.029276 \\
(2.91321) \\
\end{array}$ & $\begin{array}{l}0.760865 \\
(2.85045) \\
\end{array}$ & $\begin{array}{l}1.199309 \\
(2.11304) \\
\end{array}$ \\
\hline LDETPIB & $\begin{array}{r}0.148778 \\
(1.98763) \\
\end{array}$ & $\begin{array}{c}0.237830 \\
(1.987543) \\
\end{array}$ & $\begin{array}{l}0.1692329 \\
(2.598765) \\
\end{array}$ & $\begin{array}{l}0.7705323 \\
(2.121234) \\
\end{array}$ \\
\hline Constante & 4.953916 & -8.458072 & 1.905763 & -2.489131 \\
\hline $\mathbf{R}^{2}$ & 0.85879 & 0.229234 & 0.173409 & 0.219354 \\
\hline
\end{tabular}

Using the quadratic method, we determined the optimal debt level which corresponds to the marginal impact of external debt. This threshold corresponds to the optimal level of external debt that maximizes economic growth. It was determined, as in Pattillo et al., (2002), by solving the following formula: $\exp \left(-\frac{\beta_{\mathrm{D}}}{2 \beta_{\mathrm{D} 2}}\right)$, where $\mathrm{D}$ represents respectively DETEXP and DETPIB. 
Table 9: Threshold Debt or Point of Diversion Debt

\begin{tabular}{|c|c|}
\hline Indicator of external debt & Debt threshold or point of diversion debt $\left[\boldsymbol{e}^{-\left(\frac{\beta_{D}}{2 \beta_{D 2}}\right)}\right]$ \\
\hline DETEXP & $47,2 \%$ \\
\hline DETPIB & $30 \%$ \\
\hline
\end{tabular}

Table 7 shows the level of debt beyond which the marginal impact of external debt on economic growth becomes negative. The optimal debt level varies between 30 and $47 \%$ of GDP for the countries of North Africa

\section{Causality Between External Debt and Economic Growth}

In the context of this research, the majority of empirical studies often check simply the impact of external debt on economic growth by not addressing the possible links of cause and effect between these two indicators. In this section, we seek to investigate the causal relationship between external debt and the level of economic growth. Causality test provided by the approach of Granger (1969) had more echoes among economists (Tenou, 1996). His approach is based on a dynamic relationship between variables (Sekkat 1989 Tenou in 1996).
In the context of this research, the majority of empirical studies often focus on the verification of the impact of external debt on economic growth, disregarding the possible links of cause and effect between these two indicators. In this section, we seek to investigate the causal relationship between external debt and the level of economic growth. Causality test provided by the approach of Granger (1969) and Simis (1972) had more echoes among economists (Tenou, 1996). His approach is based on a dynamic relationship between variables (Sekkat 1989 Tenou in 1996).

In particular we are interested in the causal relationship between the three variables TCPIBH, DETPIB and DETEXP. The desired interest is whether economic growth causes the debt (TCPIBH $\rightarrow$ DETPIB and / or TCPIBH $\rightarrow$ DETEXP) or it is external debt that causes the growth rate of the economy (DETPIB $\rightarrow$ TCPIBH and / or DETEXP $\rightarrow$ TCPIBH) or rather it is a causality in both directions. The results of the causality test are listed below.

Table 10: Results of Causality Test

\begin{tabular}{|l|c|c|r|}
\hline Pairwise Granger Causality Tests & Obs & F-Statistic & Prob. \\
\hline Null Hypothesis: & 29 & 5.23046 & 0.0130 \\
\hline LDTEXP does not Granger Cause TCPIBH & & 1.06034 & 0.3620 \\
\hline TCPIBH does not Granger Cause LDTEXP & 29 & 3.40508 & 0.0499 \\
\hline LDETPIB does not Granger Cause TCPIBH & & 1.74184 & 0.1966 \\
\hline TCPIBH does not Granger Cause LDETPIB
\end{tabular}

Whatever the choice of the lag order chosen $(P=1,2,3)$, the results show that the assumption of causality (HC) is strongly rejected in all cases (TCPIBH $\rightarrow$
DETEXP and TCPIBH $\rightarrow$ DETPIB). This means that the direction of causality TCPIBH to DETEXP and to DETPIB may be rejected. However, the results show that 
there is a causal relationship in the opposite direction: strict Grager and Sims causality between DETEXP $\rightarrow$ TCPIBH and DETPIB $\rightarrow$ TCPIBH.

\section{Conclusion}

The purpose of this study was to assess the impact of external debt on economic development in a range of countries (economies of North Africa). Considering a growth model whitch combining debt ratios and the main determinants of economic growth and using dynamic panel estimation technique, the generated results showed that the impact of foreign debt on the level of economic growth is consistent with the predictions of economic theory. We can identify the following main conclusions:

- In most estimates (linear and quadratic), the variables rate of population growth and inflation rate have a negative and significant impact on the growth rate of the economy. - The investment rate, growth of human capital, changes in terms of trade and opening rate lead to economic growth. - For all estimations, an increase in the debt service has a negative and significant impact on growth, indicating that this variable affects the economy through its impact on the quality of investment and through high volume of external debt.

- The application of the linear model shows that the variables of the external debt (external debt reported successively to GDP and exports of goods and services) influence positively and significantly economic growth. This implies that the external debt in itself is not an obstacle to development in those countries whose internal resources are often limited.

- For the quadratic model, it was applied to test the hypothesis of diminishing marginal returns of foreign debt; reflecting the non-linear effect of external debt on economic growth. The coefficients of the two variables of debt taken in square are negative and statistically significant, according to the results of Clement et al., (2003). In other words, the external debt affects positively growth if it does not exceed a certain threshold. Beyond this threshold, the effect becomes negative. As a result, we can opt for the existence of a nonlinear relationship between external debt and growth, indicating that there is a threshold which would make a negative growth. This threshold, which corresponds to the marginal impact of debt, varies between $30 \%$ and $47 \%$ of GDP for the countries of North Africa.

- The revaluation model of growth without investment was done to investigate the relationship between rate investment and debt service (crowding out effect). The obtained results show that the coefficients related to the variables of debt (DETPIB, DETEXP) are both significant and different from those obtained in the presence of investment. In other words, the ratio of debt service remains significant indicating that its negative effect is transmitted by crowding out effect, but also it affects directly the rate of economic growth. This exciting result allows us to conclude that the theory of indebtedness is checked and there is a relationship between debt and growth which taking the form of an inverted $U$, indicating the presence of a Laffer curve of debt.

- The last idea addressed in this study was the notion of causality between the level of economic growth and external debt. The application of Granger and Simis technique showed a unique causal relationship between the variables of the debt and the growth rate of the economy, indicating thereby that the external debt when it well managed can enhance investment capacity and cause an increase in national wealth.

\section{References}

Adam, C. S. and D. L. Bevan (2005), "Fiscal deficits and growth in developing countries", Journal of Public Economics, 4, 571-597.

Agenor, P.R. and Montiel P., 1996. Development Macroeconomics, Princeton, New Jersey: Princeton University Pres. 
Ardagna, S., F. Caselli and T. Lane (2007) "Fiscal Discipline and the Cost of Public Debt Service: Some Estimates for OECD Countries," The B.E. Journal of Macroeconomics, 7(1).

Arslanalp, Serkan and Peter Blair Henry (2005a), "Is Debt Relief Efficient?" Journal of Finance, 60(2), 1017-1051.

Asiedu, E. 2003, « Foreign Direct Investment to Africa: The Role of Government Policy, Governance and Political Instability», Department of Economics, University of Kansas.

Barro, R. J. and Sala-i-Martin, X. (1995), Economic Growth, New York: McGraw-Hil.

Bulow, Jeremy, and Kenneth Rogoff (1990), «cleaning up the Debt crisis without getting taken to the cleaners, "Journal of Economic Perspectives, 31-42.

Cecchetti, Stephen, Madhusudan Mohanty and Fabrizio Zampolli (2011),"The real effects of debt", BIS Working Papers 352, Bank for International Settlements.

Checherita C. and P. Rother (2010), "The impact of high and growing government debt on economic growth: An empirical investigation for the euro area", $E C B$, Working Paper 1237, August.

Claessens, Stiin and Ishac Diwan (1990), " Investment Incentives: New Money, Debt Relief, and the Critical Role of Conditionality in the Debt Crisis", Tic World Bank Economic Review 4, 21-41.

Clemens Benedict J., Rina B. et Toan Quoc N. (2003), « External Debt, Public Investment and Growth in Low-incomes countries ", IMF Working Paper, WP/03/249.

Cohen D. (1995), « Large External Debt and Slow Domestic Growth », Journal of Economic Dynamics and Control, 19, 11411163.
Cohen, D. (1997), “Growth and external debt: A new perspective on the African and Latin American tragedies", Centre for Economic Policy Research Discussion, Paper No. 1753.

Cohen, Daniel. 1993. "Low Investment and Large LDC Debt in the 1980's", American Economic Review, 83(3), 437- 49.

Collier P. et Dollar D. (2002), « Aid Allocation and Poverty Reduction", European Economic Review, 46(8), 1475150.

Cordella T. Ricci L.A. Ruiz-Arranz M. (2005), "Debt Overhang or Debt Irrelevance? Revisiting the Debt-Growth Link”, IMF Working Paper No 05/223.

Corden, W. Max. (1989), "Debt relief and adjustment incentives", in Frenkel, Jacob A., Michael P. Dooley and Peter Wickham (eds.) Analytical Issues in Debt, International Monetary Fund, Washington DC.

Corsetti G., K. Kuester, A. Meier and G. Mueller (2010), "Debt consolidation and fiscal stabilization of deep recessions", American Economic Review, 100 (2), 41-45.

Dalgaard C.J. et Hansen H. (2001), « On Aid Growth and Good Policies », Journal of Development Studies, 37(6), 17-41.

De Prest E., B. Eugène and L. Van Meensel (2010), "Strategies and measures aimed at consolidating public finances", $N B B$, Economic Review, 43-63, September.

Deshpande, A. (1997), “The debt overhang and the disincentive to invest", Journal of Development Economics, 52 (1), 169-187.

Diamond, P. (1965), "National Debt in a Neoclassical Growth Model", American Economic Review, 55 (5), 1126-1150.

Dijkstra G. Hermes N. (2001), « The Uncertainty of Debt Service Payments and Economic Growth of Highly Indebted Poor Countries: Is There a Case for Debt Relief? 
», UNU/ WIDER Development Conference on Debt Relief, 17-18 août, Helsinki, Finlande.

Easterly, William. 2002. "How Did Heavily Indebted Poor Countries Become Heavily Indebted? Reviewing Two Decades of Debt Relief." World Development 30(10):16771696.

Elmendorf, Douglas W. and N. Gregory Mankiw, "Government Debt", Board of Governors of the Federal Reserve Finance and Economics Discussion Series 1998-9 (January 1998).

Ferreira C. (2009), "Public Debt and Economic Growth: a Granger Causality Panel Data Approach", Université de Lisbonne, Working paper No. 24/2009/DE/UECE.

Hansen H. et Tarp F. (2001), « Aid and Growth Regressions ", Journal of Development Economics, 64(2), 547-570.

Harrison A. (1996), “Openness and Growth, A Time-series, Cross-Country Analysis for Developing Countries", Journal of Development Economics, 48(2), 419-447.

Idlemouden K. et Raffinot M. (2005), « le fardeau virtuel de la dette extérieure ", Cahier de recherche ERISCO, $\mathrm{n}^{\circ} 2005-03$.

Johansson, P. (2010), « Debt relief, investment and growth ». World Development, doi :10.1016/j.worlddev.2009.11.021.

Krugman P. (1988), « Financing vs. Forgiving a Debt Overhang », Journal of Development Economics, 29, 253-268.

Kumar, M. and J. Woo (2010), "Public Debt and Growth", IMF Working Paper 10/174.

Lensink R. et White H. (1999), «Is There an Aid Laffer Curve? ", CREDIT Research Paper, n 99/6.

Mankiw N.G., Romer D. et Weil D.N. (1992), "A Contribution to the Empirics of Economic Growth », Quarterly Journal of Economics, 107 (2), 407-437.
Mankiw, N. G., D. Romer and D. N. Weil (1992), "A Contribution to the Empirics of Economic Growth," Quarterly Journal of Economics, 107, 407-43.

Nautel, M., \& L., Van Meensel (2011), « Economic impact of the public debt ", Economic Review, $\mathrm{n}^{\circ} 3$.

Nersisyan, Yeva, \& L. Randall Wray (2011), «Un excès de dette publique handicape-t-il réellement la croissance ? ", Revue de I'OFCE, No.116, janvier 2011.

Nicolas Depetris Chauvin \& Aart Kraay, 2005. "What Has 100 Billion Dollars Worth of Debt Relief Done for Low- Income Countries?," International Finance 0510001, EconWPA.

Ojo, O., Oshikoya, T. (1995), "Determinants of long-term growth: some African results", Journal of African economics, 4(2).

Oks, D. et Sweder W. (1995), « Mexico after the Debt Crisis: Is Growth Sustainable? », Journal of Development Economics, 47, 155178.

Panizza, Ugo, et Andra F. Presbitero (2012), « Public Debt and Economic Growth: Is There a Causal Effect? », MoFiR working paper No. 65, avril.

Pattillo C., Poirson H. et Ricci L. (2004), « What Are the Channels Through Which External Debt Affects Growth? », IMF Working Paper No. 04/15.

Pattillo, C., H. Poirson et L. Ricci (2004), "What Are the Channels Through Which External Debt A.ects Growth ?", IMF Working Paper, WP/04/15.

Pattillo, C., Poirson H. et Ricci L. (2002), « External Debt and Growth », IMF Working Paper, No. 02/69.

Presbitero, A. F (2009), « Debt-relief effectiveness and institution-building ", Development Policy Review, 27(5), 529-559.

Reinhart, Carmen M and Kenneth S Rogoff (2010a), "Debt and Growth Revisited", VoxEU.org, 11 August. 
Reinhart, Carmen M., et Kenneth S. Rogoff (2009), "This Time is Different: Eight Centuries of Financial", Journal of International Economics, 84(1), 132-134.

Reinhart, Carmen M., et Kenneth S. Rogoff (2010b), "Growth in a time of debt ", American Economic Review, 100(2).

Ricciuti, Roberto. (2003) "Assessing Ricardian equivalence," Journal of Economic Surveys 17, 55-78.

Sachs, J. (1989): "The Debt Overhang of Developing Countries," in Debt,
Stabilization and Development, ed. by G. Calvo, R. Findlay, P. Kouri, and J. B. de Macedo, Basil Blackwell, 80-102.

Sevestre P. (2002), Econométrie des données de Panel, Dunod, Paris.

Swapan S., Kasibhatla M. et Stewart D.B. (2007), « Debt overhang and economic growth: the Asian and the Latin American experiences ", Economic Systems, 31, 3-11.

Warner A.M. (1996), « Did the Debt Crisis Cause the Investment Crisis? », Quarterly Journal of Economics, 107(4). 